\title{
THE DETERMINATION OF ETHYL P-METHOXY CINNAMATE IN KAEMPFERIA GALANGA L. RHIZOME EXTRACT HARVESTED IN RAINY AND DRY SEASONS
}

\author{
INDAH SUASANI WAHYUNI ${ }^{1,2^{*}}$, IRNA SUFIAWATI ${ }^{2}$, WIPAWEE NITTAYANANTA ${ }^{3}$, JUTTI LEVITA ${ }^{1,4}$
}

1Doctoral Program in Pharmacy, Faculty of Pharmacy, Universitas Padjadjaran, Jatinangor, Sumedang, West Java, Indonesia, ${ }^{2}$ Department of Oral Medicine, Faculty of Dentistry, Universitas Padjadjaran, Bandung, West Java, Indonesia, ${ }^{3}$ Faculty of Dentistry, Thammasat University, Pathum Thani, Thailand, "4Department of Pharmacology and Clinical Pharmacy, Faculty of Pharmacy, Universitas Padjadjaran, Jatinangor, Sumedang, West Java, Indonesia.

Email: indah.wahyuni@fkg.unpad.ac.id

Received: 08 Sep 2021, Revised and Accepted: 15 Oct 2021

ABSTRACT

Objective: Kaempferia galanga L. rhizome (KGR), has been empirically used in Indonesia, particularly by Javanese, to cure inflammation. KGR contains various secondary metabolites which explain its pharmacology activities, among them is ethyl $p$-methoxycinnamate (EPMC). However, due to the different seasons of our country, the yield of extraction is often unalike. In this work, we determined the percentage of yield (w/w), the water content (thermogravimetric method), and the concentration of EPMC in the Ethanol extract of Kaempferia galanga L. Rhizome (EEKG) harvested from the rainy (EEKG-R) and dry seasons (EEKG-D).

Methods: The sun-dried rhizomes were cold macerated for $3 \times 24 \mathrm{~h}$ with $70 \%$ ethanol, filtered, and the solvent was evaporated at $40-45^{\circ} \mathrm{C}$ until a viscous extract was obtained. The determination of EPMC in the extract was carried out using the RP-HPLC standard addition method. Detection was set at $308 \mathrm{~nm}$; injection volume $20 \mu \mathrm{l}$; flow rate $1.0 \mathrm{ml} / \mathrm{min}$. The column used is C18 (length $250 \mathrm{~mm}$, internal diameter $4.6 \mathrm{~mm}$, particle size $5 \mu \mathrm{m}$ ).

Results: The yield of EEKG-R (harvested in the rainy season) $=14.56 \% \mathrm{w} / \mathrm{w}$, water content $=4.37 \%$, and the EPMC $=0.01 \%$. Meanwhile the yield of EEKG-D (harvested in the dry season) $=5.79 \% \mathrm{w} / \mathrm{w}$, water content $=18.76 \%$, and the $\mathrm{EPMC}=0.001 \%$.

Conclusion: Different climates affect the percentage yield and the quality of the extract. In our work, the EEKG-R (harvested in the rainy season) revealed a better quality compared to that of EEKG-D (harvested in the dry season) This study gives important information to standardize and optimize the harvest time of KG rhizomes for drugs development, which are strongly influenced by seasonal differences.

Keywords: Anti-inflammation, Ethyl $p$-methoxycinnamate, Herbal medicine, Kaempferia galanga L

(C) 2021 The Authors. Published by Innovare Academic Sciences Pvt Ltd.This is an open access article under the CC BY license (https://creativecommons.org/licenses/by/4.0/) DOI: https://dx.doi.org/10.22159/ijap.2021.v13s4.43841 Journal homepage: https://innovareacademics.in/journals/index.php/ijap

\section{INTRODUCTION}

Recently, the development of herbal-based drugs has become the focus of interest of many academicians and researchers. These drugs are proposed to overcome the problem of unexpected side effects by synthetic drugs. Kaempferia galanga L. (KG) rhizome, has been empirically used in Indonesia, particularly by Javanese, to relieve pain, swelling, and other inflammation [1-3].

Researches using the in vitro and the in silico technique has proven that infusion [4], methanol extract [5], ethanol extract [6, 7], petroleum extract [8], and ethyl para-methoxycinnamate (EPMC) isolated from KG rhizome [9, 10], possess an anti-inflammatory effect. EPMC, ethyl cinnamate, propanoic acid, and pentadecane are secondary metabolites contained in the essential oil of the KG rhizome. These secondary metabolites are believed to play a role in their anti-inflammatory activity [2].

Secondary metabolites in plants are part of a mechanism or selfdefense system against stress, including stress from the environment due to seasonal differences, intending to preserve the species, maintain plant immunity, and fighting pathogens that endanger its survival $[11,12]$. This is the basis for the exploration and development of medicinal plants for humans, by utilizing the secondary metabolites in these plants. As a consequence, an effort to standardize plant raw materials that can produce optimal and uniform secondary metabolites is required. Among the standardization efforts are determining the yield percentage, the water content, and the major secondary metabolite. A method that has been widely used and well-validated is the HPLC system [13-15].

In this work, we determined and compared the percentage of yield $(w / w)$, the water content (thermogravimetric method), and the concentration of EPMC in KG rhizomes harvested from the rainy and dry seasons. The results of this study will add important information to standardize and optimize the harvest time of KG rhizomes for drug development, which are strongly influenced by seasonal differences.

\section{MATERIALS AND METHODS}

\section{Materials}

The plant material used in this study was the ethanol extract prepared from the KG rhizome. The rhizomes were planted in Buniayu village, Jalan Cagak sub-district, Subang, West Java, Indonesia (6 ${ }^{\circ} 37^{\prime} 54.7^{\prime \prime S}$ $\left.107^{\circ} 41^{\prime} 59.2^{\prime \prime E}\right)$. The air temperature in the Jalan Cagak sub-district, Subang, ranges at $21-31^{\circ} \mathrm{C}$, humidity levels range from $78-84 \%$, and the average rainfall $>4000 \mathrm{~mm}[16]$. The harvested plant ages range from 8-9 mo. We obtained two harvesting times of the plants, which were in the rainy season (December) and in the dry season (June). The plant samples have been collected and certified taxonomically as previously described [17].

Chemicals used in the extract preparation and phytochemicals screening were $70 \%$ ethanol technical grade (Indokimia ${ }^{\circledR}$, Indonesia), ferric chloride solution (1-3\% in distilled water, Merck $($, Germany, CAS No. 10025-77-1), sodium hydroxide solution (1-2 $\mathrm{N}$ in distilled water, Merck®, Germany, CAS No. 1310-73-2), lead acetate solution ( $0.5 \mathrm{~N}$ in ethanol, Merck $\AA$, Germany, CAS No. 6080-56-4), sulfuric acid (Merck®, Germany, CAS No. 7664-93-9), Magnesium (Merck ${ }^{\circledR}$, Germany, CAS No. 7439-95-4), Dragendorff reagent (Merck®, Germany, CAS No. 39775-75-2), and acetic acid (Merck $\AA$, Germany, CAS No. 64-19-7). Chemicals used in the HPLC analysis were ethanol absolute analytical grade (Merck ${ }^{\circledR}$, CAT No. 1.11727.2500), acetonitrile (Merck®, CAT No. 1.00030.4000), methanol with HPLC grade (Merck®, CAT No. 1.06007.4000), double-distilled water (API IPHA®, Indonesia), and pure EPMC (Tokyo Chemical Industry Co., Ltd., CAS RN: 24393-56-4) as the internal standard. Other supporting materials used were membrane 
filters PTFE for mobile phase (pore size $=0.45 \mu \mathrm{m}$, Hawach Scientific $®$, Item code: SLPT5045SLG) and Whatman ${ }^{\text {TM }}$ filter papers (No. 1/120 $\mathrm{mm}$ and No.41/90 mm).

\section{Methods}

\section{Preparation of the extract}

The rhizome was thinly sliced and dried in a thermostatic oven (EHRET) at $50{ }^{\circ} \mathrm{C}$. The $\mathrm{KG}$ rhizome extract was prepared by soaking the dried rhizome for $3 \times 24 \mathrm{~h}$ in $70 \%$ ethanol. The collected liquid was filtered, and the filtrate was evaporated using a rotary evaporator followed by using a water bath $\left(40-45^{\circ} \mathrm{C}\right)$ to viscosity [17].

\section{Calculation of the yield percentage and the water content}

The yield percentage was measured by the formula: weight of extract divided by the weight of the macerated dry powder of KG rhizome, multiplied by 100 percent. Meanwhile, the water content is measured by weighing the extract after it was dried subsequently in an oven (Thermo scientific, OGH-100), by following the thermogravimetric method [18].

\section{Phytochemical screening}

The detected phytochemical content consisted of polyphenols, flavonoids, alkaloids, tannins, triterpenoids, and saponins. The phytochemical screening method was carried out by following the standard color test [19].
HPLC Analysis to determine EPMC in the ethanol extract of KG rhizome

HPLC analysis to determine EPMC in the ethanol extract of KG rhizome was carried out by following the optimum analytical procedure of Mukkasombut and colleagues (2020) [13], and Wahyuni and co-workers (2021) [17]. The extract samples are EEKG-R (harvested in the rainy season) and EEKG-D (harvested in the dry season). A standard EPMC solution in increased concentrations $(40,20,10,5$, and 0 ppm for EEKG-R and 3.2, 1.6, 0.8, 0.4 , and $0 \mathrm{ppm}$ for EEKG-D) was spiked to each sample. The pure EPMC (Tokyo Chemical Industry Co., Ltd., CAS RN: 24393-56-4) used as an internal standard is certified and purchased from a reputable chemical supplier. The determination of EPMC in the extract was carried out using the RP-HPLC standard addition method. Detection was set at $308 \mathrm{~nm}$; injection volume $20 \mu \mathrm{l}$; flow rate $1.0 \mathrm{ml} / \mathrm{min}$. The column used is C18 (length $250 \mathrm{~mm}$, internal diameter $4.6 \mathrm{~mm}$, particle size $5 \mu \mathrm{m}$ ). The mobile phase used was water and acetonitrile with a ratio of 40:60, in isocratic elution.

\section{RESULTS}

Table 1 shows the measurement results and the comparison between the yield percentage and water content on the EEKG-R and EEKG-D. Table 1 also shows the results of phytochemical screening results.

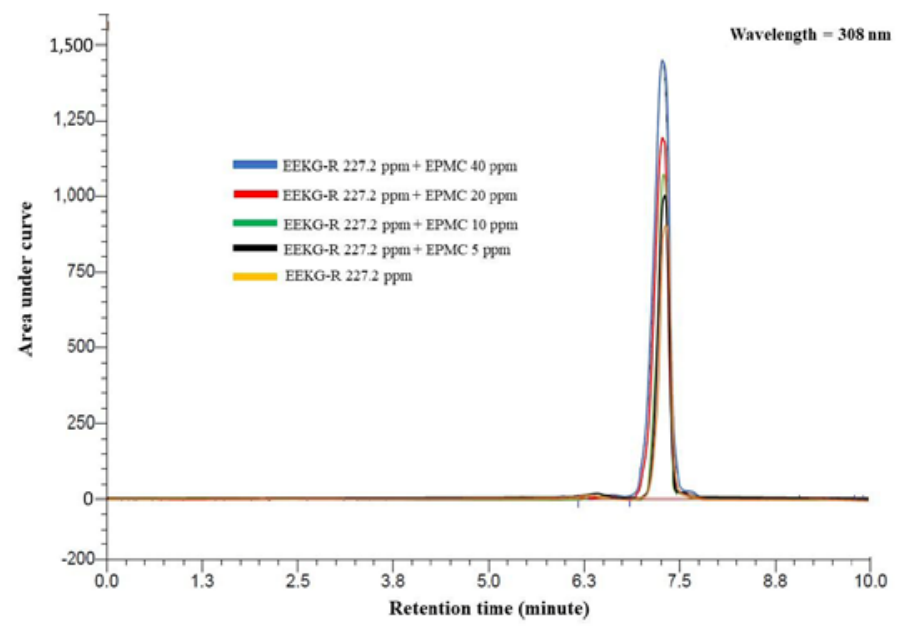

Fig. 1: Chromatogram of EEKG-R (yellow) and EEKG-R spiked with Increased Concentrations of EPMC Standard (other colors) Indicates the Presence of EPMC at $t R=7.28 \mathrm{~min}$

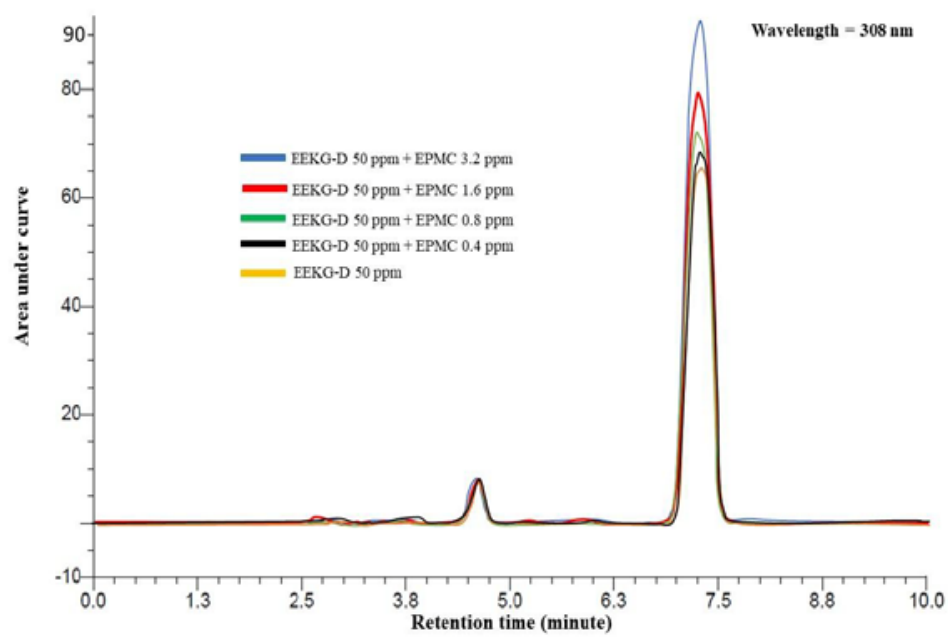

Fig. 2: Chromatogram of EEKG-D (yellow) and EEKG-D spiked with increased concentrations of EPMC standard (other colors) indicates the presence of EPMC at $t R=7.29 \mathrm{~min}$ 
Table 1: Comparison of yield percentage, water content, and phytochemical content of EEKG-R and EEKG-D

\begin{tabular}{lll}
\hline & EEKG-R & EEKG-D \\
\hline \% yield (w/w) & 5.79 \\
Water content (\%) & 14.56 & 18.76 \\
Polyphenols & 4.37 & Detected \\
Flavonoids & Detected & Detected \\
Alkaloids & Detected & Detected \\
Tannins & Detected & Detected \\
Triterpenoids & Detected & Detected \\
Saponin & Detected & Detected \\
\hline
\end{tabular}

Fig. 1 and fig. 2 depict the chromatograms produced from the EPMC analysis in EEKG-R and EEKG-D, respectively. The relative area under the curve (AUC) of EEKG-R and EEKG-D is presented in table 2 .

Table 2: HPLC data of EEKG-R and EEKG-D

\begin{tabular}{|c|c|c|c|c|c|c|}
\hline No & $\begin{array}{l}\text { The retention time } \\
\text { of EEKG-R (minutes) }\end{array}$ & $\begin{array}{l}\text { The peak height of } \\
\text { EEKG-R (mAU) }\end{array}$ & $\begin{array}{l}\text { The relative area } \\
\text { of EEKG-R (\%) }\end{array}$ & $\begin{array}{l}\text { The retention time } \\
\text { of EEKG-D (min) }\end{array}$ & $\begin{array}{l}\text { The peak height } \\
\text { of EEKG-D (mAU) }\end{array}$ & $\begin{array}{l}\text { The relative area } \\
\text { of EEKG-D (\%) }\end{array}$ \\
\hline \multirow[t]{2}{*}{ S1 } & 7.25 & 1444.69 & 98.85 & 7.28 & 92.21 & 91.73 \\
\hline & 7.25 & 1449.55 & 97.64 & 7.29 & 92.92 & 92.15 \\
\hline \multirow[t]{2}{*}{ S2 } & 7.27 & 1169.71 & 97.39 & 7.28 & 79.40 & 91.93 \\
\hline & 7.28 & 1166.52 & 97.88 & 7.28 & 79.88 & 90.28 \\
\hline \multirow[t]{2}{*}{ S3 } & 7.28 & 1066.72 & 97.12 & 7.29 & 73.90 & 90.32 \\
\hline & 7.29 & 1069.08 & 96.85 & 7.29 & 73.67 & 90.40 \\
\hline \multirow[t]{2}{*}{ S4 } & 7.29 & 1018.13 & 97.23 & 7.29 & 69.72 & 88.66 \\
\hline & 7.29 & 1018.85 & 96.58 & 7.29 & 69.95 & 88.73 \\
\hline \multirow[t]{2}{*}{ S5 } & 7.29 & 939.34 & 97.92 & 7.31 & 65.93 & 89.74 \\
\hline & 7.29 & 942.15 & 96.39 & 7.30 & 66.61 & 90.51 \\
\hline
\end{tabular}

The standard addition HPLC method shows good linearity as confirmed by the coefficient of correlation (r) value approaching 1 (table 3 ). The EPMC level in the extracts is presented in table 3.

Table 3: The determination of EPMC in the EEKG-R and EEKG-D

\begin{tabular}{lll}
\hline & EEKG-R & EEKG-D \\
\hline Linear regression equation and coefficient of & $\mathrm{y}=2.873 \mathrm{x}+244.94$ & $\mathrm{y}=2.5958 \mathrm{x}+23.344$ \\
correlation $(\mathrm{r})$ & $\mathrm{r}=0.9970$ & $\mathrm{r}=0.9930$ \\
EPMC level & $85.26 \mu \mathrm{g} / \mathrm{ml}$ or $0.01 \%(\mathrm{w} / \mathrm{v})$ & $8.47 \mu \mathrm{g} / \mathrm{ml} \mathrm{or} 0.001 \%(\mathrm{w} / \mathrm{v})$ \\
LOD & $7.57 \mu \mathrm{g} / \mathrm{ml}$ & $0.99 \mu \mathrm{g} / \mathrm{ml}$ \\
LOQ & $25.24 \mu \mathrm{g} / \mathrm{ml}$ & $3.29 \mu \mathrm{g} / \mathrm{ml}$ \\
\hline
\end{tabular}

\section{DISCUSSION}

Polyphenols, flavonoids, alkaloids, tannins, triterpenoids, and saponin were detected in both EEKG-R and EEKG-D (table 1). Our previous study confirmed that polyphenols were contained in the extracts harvested in the rainy season, using thin-layer chromatography (TLC), spectrophotometry, and HPLC [17].

The percentage yield of EEKG-R is higher than that of EEKG-D, whereas the water content of EEKG-R is lower than that of EEKG-D (table 1). The optimum requirement for the synthesizing of extracts from Kaempferia galanga L. rhizome is to produce yield $>8 \%$ and water content $<10 \%$ [20]. Several studies stated that the synthesis of extracts of Kaempferia galanga L. rhizome using the cold maceration method with $96 \%$ ethanol resulted in varying yields of $4 \%$ [8], 5.86\% [7], 12.67\% [21], and 20.56\% [22]. Other studies confirmed that EPMC had been isolated from the active sub-fraction of a chloroform extract KG (yield $=0.026 \%$ ) [9]. However, none reported the comparison between yield, water content, and the concentration of EPMC in KG rhizomes harvested from different climates.

The difference in the yield percentage and the water content proved that climate is important in affecting the yield. The best planting time for KG is at the beginning of the rainy season and harvesting is usually done after 11 mo at the next rainy season [21]. During the dry season, the plants get access to the water from deeper sources, while in the rainy season most of the water is obtained from the upper soil layers. Thus, in the rainy season, shallow lateral roots or rhizomes remain well-hydrated $[23,24]$.
The chromatogram peaks of EEKG-R and EEKG-D, detected at 308 $\mathrm{nm}$, indicating that EPMC is positively contained in both extracts and is eluted at $7.2 \mathrm{~min}$. The rhizome harvested in the rainy season resulted in a higher EPMC level than that of the dry season. The EEKG-R shows better quality than the EEKG-D, thus the best harvesting time for KG is the rainy season.

There are various methods of extracting KG rhizome, e. g. maceration using ethanol [7, 8, 17, 21, 22, 26, 27], maceration using dichloromethane [28], hydro-distillation at $100-105{ }^{\circ} \mathrm{C}$ [29], serial extractions using petroleum ether, chloroform, methanol, and water $[9,10]$, etc, however, the level of EPMC reported by previous authors is not unalike, which is very low and in line with our result.

\section{CONCLUSION}

Different climates affect the percentage yield and the quality of the extract. In our work the EEKG-R (harvested in the rainy season) revealed a better quality (yield $=14.56 \% \mathrm{w} / \mathrm{w}$, water content $=$ $4.37 \%$, EPMC $=0.01 \%$ ) compared to that of EEKG-D (harvested in the dry season) (yield $=5.79 \% \mathrm{w} / \mathrm{w}$, water content $=18.76 \%$, EPMC $=0.001 \%$ ). This study gives important information to standardize and optimize the harvest time of $\mathrm{KG}$ rhizomes for drugs development, which are strongly influenced by seasonal differences.

\section{ACKNOWLEDGEMENT}

This research is supported by Riset Disertasi Dosen Unpad (RDDU) and Academic Leadership Grant of Universitas Padjadjaran No. 1427/UN6.3.1/1T/2020. This manuscript is a part of the doctoral research of Indah Suasani Wahyuni. 


\section{AUTHORS CONTRIBUTIONS}

All the authors have contributed equally.

\section{CONFLICTS OF INTERESTS}

There are no conflicts of interest.

\section{REFERENCES}

1. Aroonrerk N, Kamkaen N. Anti-inflammatory Activity of Quercus infectoria, Glycyrrhiza uralensis, Kaempferia galanga and Coptis chinensis, the Main Components of Thai Herbal Remedies for Aphthous Ulcer. J Health Res. 2009;23(1):17-22.

2. Umar I. Phytochemistry and medicinal properties of Kaempferia galanga L. (Zingiberaceae) extracts. (Zingiberaceae) extracts. Afr J Pharm Pharmacol. 2011;5(14):1638-47. doi: 10.5897/AJPP11.388.

3. Kusumawati I, Hestianah EP, Yusuf H. Republic; 2018. Available from:

https://www.researchgateResearchgate.net/publication/33040 9630_Topical_Analgesic_from_Kaempferia_galanga_extract Indonesia Patent IDP000053030. [Last accessed on 07 Oct 2021]

4. Levita J, K. Wijaya LK, Celcilia S, Mutakin M. Inhibitory activity of kaempferia galanga and hibiscus sabdariffa on the Rate of PGH2 formation. J Appl Sci. 2015;15(7):1032-6. doi: 10.3923/jas.2015.1032.1036.

5. Ridtitid W, Sae-wong C, Reanmongkol W, Wongnawa M. Antinociceptive activity of the methanolic extract of Kaempferia galanga Linn. in experimental animals. J Ethnopharmacol. 2008;118(2):225-30. doi: 10.1016/j.jep.2008.04.002, PMID 18486374 .

6. Samodra G, Febrina D. Anti-inflammatory Effects of Kaempferia galanga L. rhizome extract in carrageenan-induced female rats. Adv Health Sci Res. 2019;20(1):13-7.

7. Riasari H, Rachmaniar R, Febriani Y. Effectiveness of antiinflammatory plaster from Kencur (Kaempferia Galanga L.) rhizome ethanol extract. Int J Pharm Sci Res. 2016;7(4):1746-9.

8. Jagadish PC, Latha KP, Mudgal J, Nampurath GK. Extraction, characterization and evaluation of Kaempferia galanga $\mathrm{L}$. (Zingiberaceae) rhizome extracts against acute and chronic inflammation in rats. J Ethnopharmacol. 2016;194:434-9. doi: 10.1016/j.jep.2016.10.010, PMID 27720847.

9. Umar MI, Asmawi MZ, Sadikun A, Atangwho IJ, Yam MF, Altaf R, Ahmed A. Bioactivity-Guided Isolation of ethyl-pmethoxycinnamate, an anti-inflammatory Constituent, from Kaempferia galanga L. extracts. Molecules. 2012;17(7):872034. doi: 10.3390/molecules17078720, PMID 22825623.

10. Umar MI, Asmawi MZ, Sadikun A, Majid AMSA, Al-Suede FSR, Hassan LEA, Altaf R, Ahamed MB. Ethyl-p-methoxycinnamate isolated from Kaempferia galanga inhibits inflammation by suppressing interleukin-1, tumor necrosis factor- $\alpha$, and angiogenesis by blocking endothelial functions. Clinics (Sao Paulo). 2014;69(2):134-44. doi: 10.6061/clinics/2014(02)10, PMID 24519205.

11. Yang L, Wen KS, Ruan X, Zhao YX, Wei F, Wang Q. Response of plant secondary metabolites to environmental factors. Molecules. 2018;23(4):762. doi: 10.3390/molecules23040762, PMID 29584636.

12. Isah T. Stress and defense responses in plant secondary metabolites production. Biol Res. 2019;52(1):39. doi: 10.1186/s40659-019-0246-3, PMID 31358053.

13. Mukkasombut N, Pipatrattanaseree W, Itharat A. Validation of HPLC method for the determination of anti-allergic compounds in ethanolic extract of prasaprohyai remedy, a thai traditional medicine. Thammasat Med J. 2020;20(1):74-83.

14. Kaushita B, Priya CL, Rao KVB. HPLC analysis and antioxidant activities of hydroethanolic leaf extract of Kaempferia galanga Linn. Int J PharmTech Res. 2014;7(2):422-31.
15. Raj R, Chandrashekar KS, Biswas R, Pai A, Pai V. Rapid highperformance thin layer chromatographic quantitative estimation of caffeine in various foods and beverages. Rasayan J Chem. 2021;14(1):221-6. doi: 10.31788/RJC.2021.1415991.

16. daerah Kabupaten P. Sumedang. Iklim [internet]. Available from: https://www.subang.go.ID/profil/iklim. [Last accessed on 10 Jul 2021]

17. Wahyuni IS, Sufiawati I, Nittayananta W, Levita J. Identification of ethyl para-methoxycinnamate and kaempferol in the ethanol extract of Kaempferia galanga L. Rhizome as biomaterial for drug candidate using spectrophotometric and chromatographic analysis. Mater Sci Forum. 2021;1028:371-6. doi: 10.4028/www.scientific.net/MSF.1028.371.

18. Saadatkhah N, Carillo Garcia AC, Ackermann S, Leclerc P, Latifi M, Samih S, Patience GS, Chaouki J. Experimental methods in chemical engineering: thermogravimetric analysis-TGA. Can J Chem Eng. 2020;98(1):34-43. doi: 10.1002/cjce.23673.

19. Tiwari P, Kumar B, Kaur M, Kaur G, Kaur H. Phytochemical screening and extraction: a review. Int Pharm Sci. 2011;1(1):98-106.

20. Kementerian kesehatan republik Indonesia. Direktorat Jendral Kefarmasian dan Alat Kesehatan. Farmakope Herbal Indonesia; 2017.

21. Nurani LH, Asahi A, Susanti H. Determination of epms content and anti-inflammatory test rhizome extract Kaempferia galanga, L by inhibition of protein denaturation method. Pharmaciana. 2020;10(3):381-90. doi: 10.12928/pharmaciana.v10i3.15293.

22. Riasari H, Rachmaniar R, Wahyuni S. Evaluation patch of rhizoma extract kencur (Kaempferia galanga L.) as antiinflammatory with enhancer. Indonesian J Pharm Sci Technol. 2019;6(2):59-64. doi: 10.24198/ijpst.v6i2.18932.

23. Cekur KH. (Kaempferia galanga L.) in: Penanaman Tumbuhan Ubatan and Beraroma [Internet]. Com/index. php? option=com_contentandview=articleandid=106089:kaempferi a-galanga-land catid=286andItemid=357\#r6. Available from: https://globinmed. [Last accessed on 07 Oct 2021]

24. Lee JE, Oliveira RS, Dawson TE, Fung I. Root functioning modifies seasonal climate. Proc Natl Acad Sci USA. 2005;102(49):17576-81. doi: 10.1073/pnas.0508785102. PMID 16301519.

25. Dawson TE, Pate JS. Seasonal water uptake and movement in root systems of Australian phraeatophytic plants of dimorphic root morphology: a stable isotope investigation. Oecologia. 1996;107(1):13-20. doi: 10.1007/BF00582230, PMID 28307187.

26. Sirisangtragul W, Jarukamjorn K, Nemoto N, Yenjai C, Sripanidkulchai B. Effect of ethyl-p-methoxy cinnamate from Kaempferia galanga on cytochrome P450 enzymes expression in mouse hepatocytes. Chiang Mai J Sci. 2011;38(3):453-62.

27. Amuamuta A, Plengsuriyakarn $\mathrm{T}$, Na-Bangchang $\mathrm{K}$. Anticholangiocarcinoma activity and toxicity of the Kaempferia galanga Linn. Rhizome ethanolic extract. BMC Complement Altern Med. 2017;17(1):213. doi: 10.1186/s12906-017-17134, PMID 28403856.

28. Sasidharan S, Chen Y, Saravanan D, Sundram KM, Yoga Latha LY. Extraction, isolation and characterization of bioactive compounds from plants' extracts. Afr J Tradit Complement Altern Med. 2011;8(1):1-10. doi: 10.4314/ajtcam.v8i1.60483, PMID 22238476.

29. Srivastava N, Ranjana, Singh S, Gupta AC, Shanker K, Bawankule DU, Luqman S. Aromatic ginger (Kaempferia galanga L.) extracts with ameliorative and protective potential as a functional food, beyond its flavor and nutritional benefits. Toxicol Rep. 2019;6:521-8. doi: 10.1016/j.toxrep.2019.05.014, PMID 31431884 